(1) with different breeds, (2) with different individuals of the same breed, (3) with time and manner of milking, ( $t$ ) the relation is quite uniform cluring the first eight or nine months of lactation, after which the albumin increases relatively nore than the cascin.

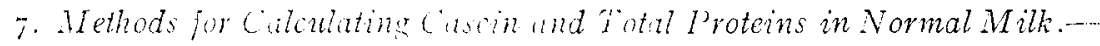
In the case of herd nilk containing 3 . wo to 4.50 per cent. of fat, the following fommla for calculating the amount of casein has been found to give, in most cases. (quite satisfactory results:

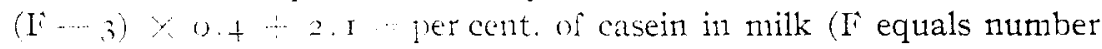
representing per cent. of fat in milk). Total proteins in milk can be roughly estimated by the following modification of the preceding formula: (1 ....3) $\times 0.4+2.8=$ per cent. of proteins in milk.

8. The Relation oj Fat and (iwein in Milk to Yield of Cheese---In milk of average composition ( 3.6 to 3.8 per cent. of fat) the yield of fresh cheese from 100 pounds of milk may be ascertained by multiplying the number representing the per cont. of fat in milk by 2.7 . The yield of cheese may be calculated more closely for milks containing fat below 3.6 or above 3.8 per cent. when the per cent. of both fat and of casein in milk is known, as follows: (Casein $\times 2.5)+(1$ at $\times$ I.I) $=$ pounds of fresh cheese makte from roo ponids of milk.

9. The Rolation of Fat and (asin in .Milk o composition and Quality of Cheoe... Cheese nade irom milk in which fat is high relative to casein is superior in quality to cheese made from milk in which fat is low relative to casein. Slim-milk checse, whole-nilk cheese and cream cheese owe their differences in quality to the difference in relation of fat to casein in nilk.

Io. The Relation of fiat to Proteins in Mith as a Basis for Detecting Skimmed Milk and Skimmed milk Cheese.--In the case of herd milk as commonly found in New Yorls State, the milk is open to the suspicion of being skimmed when the percentage of fat is less than that of proteins. cheese of the chedlar type which conta ns more than I part of proteins for 1.2 parts of fat is mate from skimmed milk.

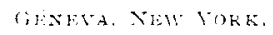

\title{
QUANTITY AND COMPOSITION OF DRAINAGE WATER AND A COMPARISON OF TEMPERATURE, EVAPORA- TION AND RAINFALL.
}

\author{
BY J. H. NORTON. \\ Received May 2, ryos.
}

The time chosen for conducting this experiment was the year of $\mathbf{1 9 0 6}$. The drainage water taken was that of Richland creek, which drains a territory of $84,95+$ acres. This valley is located in the southwestern part of Marlison and the custern part of Washington Counties in the 
state of Arkansas, with about nine-elevenths of the territory in the former county.

This region is especially adapted to this experiment as it is a purely agricultural one, which contains only five post-offices with a total population of these offices of 265 and is one in which, as far as can be ascertained, no commercial fertilizers have been used.

The rainfall for this territory was obtained from the four rainfall stations of the United States Weather Bureau located near the boundary of this valley. The rainfall for each station was taken as applying to that particular territory which was nearest that station.

This experiment was conducted by making determinations on the stream every two weeks, with one period of fifteen days, and the calculations made by taking each period as one twenty-sixth of a year. The velocity of the water was determined by the use of a current meter made by Gurley, of Troy, N. Y. The velocity taken each time was the resultant of from nine to twenty-two determinations. A sample of water was taken at the time the other determinations were made and analyzed. The water flow determinations would have been more nearly exact if the water could have been made to go through a water meter, but such an undertaking was not feasible for this stream and to have taken a smaller stream would have left a source of error in the underground drainage. It is true that one day's flow of the stream is seldom, if ever, an average day for the year. It is believed that taking the samples at regular intervals of time for twenty-six times will compensate errors and give totals for the whole year, which are very near the real amounts.

The chemical analyses for chlorine, nitrogen, total solids, loss on ignition and the reactions were made just as soon as possible after the samples were procured and the evaporation of the ro liters were made usually within five days. After the evaporations were made the residues were transferred to a small beaker and set aside until the close of the year; then all were analyzed at the same time, using two blanks and making corrections for the reagents.

The chemical analysis of the water was made as follows: For total solids, direct determination, Ioo cc. of the water were evaporated to dryness in a tared platinum dish and weighed; then heated to a dull red and reweighed for loss on ignition. For nitrogen the determination was made by running duplicates and blanks as prescribed in the Gunning method, modified to include nitrates using $500 \mathrm{cc}$. of the water in each case. The chlorine was determined by the method found in "Examination of Water" by, Mason. The other determinations were made gravimetrically by evaporating so liters to dryness in a Royal Berlin porcelain evaporating dish which had a capacity of I liter. This evaporation was conducted on the water bath with an inverted funnel over the dish 
containing a plug of glass wool in the stem. This same dish was used for each evaporation so as to make sure that no solids were lost by remaining in the dish. At the end of the year only a slight coloration could be detected; no deposit could be detected; and the glazing seemed to be perfect in the dish.

During the last sixteen years the annual rainfall has exceeded that of I 906 only three times. The maximum rainfall occurred in 1905 and this, it seems, would have a tendency to make the drainage water, or rather the effect of the drainage water, about normal for the year of 1906 .

\begin{tabular}{|c|c|c|c|c|}
\hline Date. & $\begin{array}{l}\text { Cu. ft. of } \\
\text { drainage water } \\
\text { per minute. }\end{array}$ & $\begin{array}{l}\text { Cu. ft. of } \\
\text { drainage water per } \\
\text { acre in } 126 \text { year. }\end{array}$ & $\begin{array}{c}\text { C11. ft. of } \\
\text { rainfail per } \\
\text { acre in } 1 / 26 \text { year. }\end{array}$ & $\begin{array}{l}\text { Cu. ft. of water } \\
\text { evaporated fromone } \\
\text { acre in } 1 / 26 \text { year. }\end{array}$ \\
\hline Jan. & $6 \ldots \ldots \ldots I 8.588 .00$ & +425.90 & 7960.60 & .3543 .70 \\
\hline Ian. & $20 \ldots \ldots \ldots+39,5.50$ & $10+6.60$ & 726.00 & -320.60 \\
\hline Feb. & $3 \ldots \ldots \ldots 10,5+2.40$ & 2.510 .00 & 15282.00 & 12772.00 \\
\hline Feb. & $17 \ldots \ldots .9+5+.30$ & $22,51,000$ & 4138.00 & 1887.20 \\
\hline Mar. & $3 \ldots \ldots \ldots 130300.00$ & .310 .50 & 7078.50 & .3062 .00 \\
\hline Mar. & $I 7 \ldots \ldots \ldots I 5 I 60.80$ & 36 I I So & 544.5 .00 & $18,3,3.20$ \\
\hline Mar. & $3 \pi \ldots \ldots .16-10.00$ & .3980 .80 & $2069 \mathrm{~T} .00$ & $I 67 I I .20$ \\
\hline April & $14 \ldots \ldots \ldots 53104.20$ & $12.3,50.00$ & 92.56 .60 & $-30099 \cdot 40$ \\
\hline April & $28 \ldots \ldots \ldots+7+7 \cdot 30$ & $11,30.40$ & 470.80 & -6.59 .60 \\
\hline May & $12 \ldots \ldots \ldots .5344 .60$ & $\therefore+4 . \infty$ & 0082.50 & $91.38,50$ \\
\hline May & $26 \ldots \ldots \ldots \quad \mathrm{I} 25,54.50$ & 204.70 & 1270.50 & 971.80 \\
\hline Inne & $0 \ldots \ldots, 70103.000$ & $1(x(x) 2, x)$ & 2.3740 .50 & 7048.50 \\
\hline June & $2,3 \ldots \ldots \ldots \quad$ I0901.20 & $+7+10$ & 7151.20 & 6675.10 \\
\hline Iuly & $7 \ldots \ldots$ & 156.14 & 3153.20 & 2972.06 \\
\hline July & $21 \ldots \ldots$ & $(1)(1) .72$ & 8312.80 & 8122.08 \\
\hline Aug. & $4 \ldots \ldots$ & I $39.5 \%$ & $4029 \cdot 30$ & $3889 \cdot 72$ \\
\hline Aug. & $2200+10$ & 525.39 & 22797.00 & 22271.62 \\
\hline Sept. & I $\ldots \ldots \ldots$ & $+t^{6} \cdot(x)$ & I $1,54,3 \cdot 50$ & 11097.50 \\
\hline Sept. & $15 \ldots \ldots \ldots \quad 4623.32$ & $\operatorname{IInO} .80$ & 1.3031 .60 & $\operatorname{II} 930.80$ \\
\hline Sept. & $29 \ldots \ldots \ldots \quad 1543.04$ & 367.40 & 39.56 .70 & $3.589 \cdot 30$ \\
\hline Oct. & $1.3 \ldots \ldots \ldots$ & 100.80 & $399 \cdot 30$ & 208.50 \\
\hline Oct. & $28 \ldots \ldots \ldots$ & 9.5 .94 & $330,3 \cdot 30$ & $3207 \cdot 31$ \\
\hline Nov. & II $\ldots \ldots \ldots$ & $30.8+$ & 47.90 & 381.00 \\
\hline Nov. & $25 \ldots \ldots \ldots{ }_{1561} \&_{7}$ & 371.87 & 8094.80 & 7722.93 \\
\hline Dec. & $9 \ldots \ldots \ldots \quad 5892.1 \mathrm{I}$ & 1402.00 & $505.3 \cdot 20$ & $4550 \cdot 30$ \\
\hline Dec. & $23 \ldots \ldots .6823 .68$ & $162+.70$ & 5263.60 & $3^{6} 38.90$ \\
\hline Total & & 59470.02 & 202520.00 & 143049.08 \\
\hline
\end{tabular}

The reaction of the water at the temperature of the laboratory was alkaline with cochineal in every case. This water was not alkaline with phenolphthalein at the boiling point from June 9 to August 4 nor was it alkaline in December with this reagent. It is certainly to be expected that the alkalinity during the growing season would be less than at other seasons of the year, which was the case. But the decline of alkalinity in December is unaccounted for.

The drainage water from this valley gave the following number of pounds of material removed from one acre of soil in one year: Total solids, 
794.638 ; silica, 349.296 ; loss on ignition, I34.13423; alumina, 86.467 ; lime, $80.79 \mathrm{I}$; sulphur trioxide, I 7.728; chlorine, 13.58029 ; magnesia, Io.065; potassium oxide, 4.8I7; nitrogen, 4.0II53; sodium oxide, 3.010; ferric oxide, r.089; manganous manganic oxide, 0.953; phosphorus pentoxide, 0.657 .

\section{The mean daily Per cent.}

Date. $\quad \overbrace{\text { Temperature. Rainfall. }}^{\text {Evaporation. }} \begin{gathered}\text { of rainfall } \\ \text { evaporated. }\end{gathered}$

\begin{tabular}{|c|c|c|c|c|c|}
\hline Jan. & $6 \ldots \ldots \ldots \ldots$ & 34.8 & 0.237 & 0.1148 & 40 \\
\hline Jan. & $20 \ldots \ldots \ldots \ldots \ldots$ & $4 I .6$ & 0.014 & 0.0059 & 42 \\
\hline Feb. & $3 \ldots \ldots \ldots \ldots \ldots$ & 37.6 & 0.301 & o. I 324 & 44 \\
\hline Feb. & $17 \ldots \ldots \ldots \ldots$ & $3 I \cdot 2$ & $0.08 \mathrm{I}$ & 0.0373 & 46 \\
\hline Mar. & $3 \ldots \ldots \ldots \ldots \ldots$ & $46 . I$ & 0.139 & 0.0667 & $4^{8}$ \\
\hline Mar. & $\mathrm{I}_{7} \ldots \ldots \ldots \ldots \ldots$ & $3^{8} \cdot \mathrm{I}$ & 0.107 & 0.0535 & 50 \\
\hline Mar. & 3 I $\ldots \ldots \ldots \ldots \ldots$ & $43 \cdot 2$ & 0.407 & 0.2116 & 52 \\
\hline April & $\mathbf{r}_{4} \ldots \ldots \ldots \ldots$ & 59.8 & 0.182 & 0.0983 & 54 \\
\hline April & $28 \ldots \ldots \ldots \ldots \ldots$ & $64 \cdot 5$ & 0.009 & 0.0050 & 56 \\
\hline May & $\mathbf{I} 2 \ldots \ldots \ldots \ldots$ & $63 \cdot 9$ & 0.196 & 0.1176 & 60 \\
\hline May & $26 \ldots \ldots \ldots \ldots \ldots$ & 71.8 & 0.024 & 0.0156 & 65 \\
\hline June & $9 \ldots \ldots \ldots \ldots$ & 71.6 & 0.460 & 0.3220 & 70 \\
\hline June & $23 \ldots \ldots \ldots \ldots$ & 70.6 & $0.14 \mathrm{I}$ & O. I3II & 93 \\
\hline July & $7 \ldots \ldots \ldots \ldots$ & $74 \cdot I$ & $0.06 \mathrm{I}$ & 0.0573 & 94 \\
\hline July & $2 I \ldots \ldots \ldots \ldots \ldots$ & $74 \cdot 9$ & $0.16 I$ & 0.1546 & 96 \\
\hline Aug. & $4 \ldots \ldots \ldots \ldots$ & $75 \cdot 2$ & 0.079 & 0.0758 & 96 \\
\hline Aug. & $18 \ldots \ldots \ldots \ldots$ & 76.5 & 0.449 & 0.4310 & 96 \\
\hline Sept. & $\mathbf{I} \ldots \ldots \ldots \ldots$ & $74 \cdot 4$ & 0.227 & 0.2179 & 96 \\
\hline Sept. & $15 \ldots \ldots \ldots \ldots \ldots$ & 76.4 & 0.256 & 0.2406 & 94 \\
\hline Sept. & $29 \ldots \ldots \ldots \ldots \ldots$ & 71.6 & 0.076 & 0.0699 & 92 \\
\hline Oct. & $13 \ldots \ldots \ldots \ldots$ & $60 \cdot 4$ & 0.008 & 0.0072 & 90 \\
\hline Oct. & $28 \ldots \ldots \ldots \ldots \ldots$ & 56.7 & 0.061 & 0.0537 & 88 \\
\hline Nov. & $I I \ldots \ldots \ldots \ldots$ & 53.8 & 0.009 & 0.0076 & 85 \\
\hline Nov. & $25 \ldots \ldots \ldots \ldots \ldots$ & $42 \cdot 5$ & 0.159 & 0.1272 & 80 \\
\hline Dec. & $9 \ldots \ldots \ldots \ldots \ldots$ & 50.5 & 0.117 & 0.0878 & 75 \\
\hline Dec. & $23 \ldots \ldots \ldots \ldots$ & $\begin{array}{r}38.9 \\
\end{array}$ & 0.104 & 0.0728 & 70 \\
\hline Tot & & $\cdots$ & 5 I. I6(? $)^{1}$ & $\cdots \cdots$ & $\ldots$ \\
\hline Mer & & $57 \cdot 9$ & O.I 53 & $\ldots \ldots$ & 70.63 \\
\hline
\end{tabular}

The composition of these total solids by percentage is as follows: Silica, 43.96; loss on ignition, I6.88; alumina, I0.88; lime, I0.17; sulphur trioxide, 2.23I ; chlorine, I.709; magnesia, I.266; potassium oxide, o.606; nitrogen, 0.505 ; sodium oxide, 0.379; ferric oxide, 0.137; manganous manganic oxide, 0.120 ; phosphorus pentoxide, 0.083 ; this leaves an amount unaccounted for which equals II.07\%. Calculating the calcium and magnesium as the carbonates would give $9.37 \%$ carbon dioxide, this still leaves unaccounted-for solids which amount to $1.70 \%$. This discrepancy, in the writer's opinion, should be added to the loss on ignition, for when it is considered that the loss on ignition was made on amounts which were usually less than Io milligrams and that there is great difficulty in burning all the organic matter without decomposing the carbonates it would seem reasonable that there was not complete combustion.

1 The column as printed adds up to $4.065 .-$ EDITor. 
The composition of the soil of this region is approximated from eleven analyses of three soils in this locality just outside of the Rishland valley. The following average percentage composition is obtained for the surface six inches of soil from these analyses:-water, 5.53 ; silica, 86.67; alumina, 3.16; lime, 0.20; sulphur trioxide, o.11; magnesia, o.16; potassium oxide, o.II; nitrogen, 0.06I; sodium oxide, 0.16; ferric oxide, 2.22 ; manganous manganic oxide, O.I2; and phosphorus pentoxide, O.I I 2. These figures probably represent very well the soil of the Richland valley except for the lime and magnesia which are omitted from the discussion.

Taking the weight of one cubic foot of soil as 70 pounds, this would mean that the drainage water removes 0.00313 inch of soil annually, or it would require about 300 years to remove one inch of soil by drainage water.

The loss by drainage water is great enough to remove all of each of the elements to the following depths in inches annually: Silica, o.00152; alumina, o.oro33; sulphur trioxide, 0.06082 ; potassium oxide, o.01653; nitrogen, 0.02482 ; sodium oxide, 0.00710 ; ferric oxide, 0.00019 ; manganous manganic oxide, 0.00300 ; phosphorus pentoxide, $0.0022 \mathrm{I}$. In other words, the tendency of the drainage water is to accumulate silica, iron, manganese and phosphorus in the soil and a tendency to lose aluminium, sulphur, potassium, nitrogen and sodium. The tendency to the accumulation of phosphorus is so very slight that it is negligible when the amount of that element removed by plant growth is taken into consideration. The loss of nitrogen is about equal to that supplied by rainfall. The Rothamsted station gives the nitrogen of rainfall on one acre per year as 3.3 to 4.43 pounds while the Kansas station gives 3.44 pounds. The loss of potassium is very marked and since the soil is already very deficient in this element it is a question of no little importance. On the other hand the loss of sulphur is certainly a benefit, as this soil already contains an excess of this element.

The conclusions are:

(I) On the whole, the erosion due to drainage water is not serious when it requires 300 years to remove one inch of soil.

(2) The annual loss per acre due to drainage water amounts to: nitrogen, sixty cents; potassium, twenty five cents; and phosphorus, about four cents. This would make an annual loss per acre of eighty-nine cents.

(3) During the growing season the evaporation amounts to more than ninety per cent. of the rainfall, while for the whole year the evaporation amounts to seventy per cent. of the rainfall. 